\title{
Isolation and Characterization of Predominant Bacteria, Staphylococcus piscifermentans Associated with Traditional Fermented Fish Products of Northeast India
}

\author{
Shubham Gupta ${ }^{1}$, Ravindra ${ }^{2}$, Pradip K. Maurya ${ }^{1}$, Janmejay Parhi ${ }^{1}$, Sanjeev Sharma ${ }^{1}$, \\ Sanjay Chandravanshi ${ }^{1}$ and Ranendra K. Majumdar ${ }^{*}$ \\ ${ }^{1}$ College of Fisheries, C.A.U., Tripura-799210, India \\ ${ }^{2}$ ICAR-National Bureau of Fish Genetic Resources, Canal Ring Road, P.O. Dilkusha, \\ Lucknow- 226 002, Uttar Pradesh, India \\ *Corresponding author
}

\begin{tabular}{|c|}
\hline Keywords \\
\hline $\begin{array}{l}\text { Staphylococcus } \\
\text { piscifermentans, } \\
\text { Northeast India, } \\
\text { Fermented fish, Probiotic } \\
\text { properties }\end{array}$ \\
\hline Article Info \\
\hline $\begin{array}{l}\text { Accepted: } \\
16 \text { April } 2018 \\
\text { Available Online: } \\
10 \text { May } 2018\end{array}$ \\
\hline
\end{tabular}

\section{Introduction}

Consumers' awareness and interest for fermented foods is steadily increasing. Various fermented food products are available in the market having great probiotic
Traditional fermented fish products are known for their rich probiotic values. In the present study, an effort was made to isolate and characterize the indigenous predominant LAB strain from commercially important four fermented fish products (Shidal, Lonailish, Ngari and Hentak) consumed in north-eastern regions of India, and further characterized their probiotic properties. A total 10 isolates were identified as Staphylococcus piscifermentans on the basis of biochemical and molecular characterization. These isolates were screened from MRS agar plate with typical yellowish colony and found positive to Gram stain and catalase whereas negative to cogulase. These isolates were confirmed by amplification of Staphylococcus rpoB gene using specific primers and sequencing. BLAST-n analysis of rpoB sequence (Accession Number: KX582169.1) revealed maximum similarity (100\%) with Staphylococcus piscifermentans (Accession Number: HM146320.1). Further evaluation of probiotic properties, all isolates were found non-hemolytic on blood agar plate and non-pathogenic on the basis of its susceptibility against most of the antibiotics. These isolate displayed antagonistic effect against pathogenic strain of $E$. coli and Staphylococcus aureus. In addition, survivability to bile salt $(0.3 \%)$ and different $\mathrm{pH}$ value (2.0-8.0) indicates resistance to gastrointestinal tract environment. These isolates displayed significant value of hydrophobicity $(33.4 \%)$ as well as auto-aggregation $(72.9 \%)$ which indicates its ability to adhere to the intestinal epithelial wall. The results obtained from this study, provide information regarding application of $S$. piscifermentans strain as a potent starter culture in fish fermentation industries. 
directly or indirectly in daily life to maintain well-being (Gong et al., 2017). Fermented foods play important roles in human nutrition and food security (Narzary et al., 2016). The reasons of popularities of fermented foods because of these products are rich source of probiotic, which have numerous therapeutic benefits such as anti-hypertension, anticancer, hypoglycemic properties, antioxidant, and immune modulatory effects (Khan, 2014). LAB are most investigated probiotic because of their safe role in food fermentations for millennia (Papadimitriou, 2015), technological properties and Generally Recognised as Safe (GRAS) status. Therefore, LAB are considered as microorganisms of prime interest in food fermentation. Acids produced by LAB during fermentation, helps to improve safety and quality of the fermented products via maintaining low $\mathrm{pH}$ and improving to the taste, aroma and texture (Visessanguan et al., 2006). LAB can also modify the carbohydrate content of foods, synthesize amino acids, improve the availability of B-group vitamins, degrade anti-nutrients, and thus increase the availability of iron, zinc and calcium (Blandino et al., 2003). Furthermore, LAB have the properties to enhance flavour and digestibility of fermented food, improve nutritional value and pharmaceutical values (Jeyaram et al., 2009) as well as acts as natural antimicrobial agents (Ouwehand and Vesterlund, 2004). In addition, they produce bioactive compounds/peptides during food processing or food digestion hence, positively affect human health (Muro Urista et al., 2011).

LAB are the group of beneficial microorganisms, mostly isolated from various fermented food products globally (Tamang et al., 2012) such as Staphylococcus carnosus, $S$. piscifermentans, S. cohnii, S. xylosus (Zaman et al., 2011), Lactobacillus plantarum, L. casei, L. farciminis, L. pentosus (Matsui et al., 2010), Bacillus amyloliquefaciens and $B$. licheniformis (Toyokawa et al., 2010) have been frequently reported. Although, lot of LAB strain has been known today, but continuous research is still going on for the isolation of medically and industrially important new probiotic strains.

The Staphylococcus spp. found in various fermented foods including fermented fish, soy sauce, fermented sausages, and traditional salted meat (Tanasupawat et al., 1992; Probst et al., 1998). Isolation of different Staphylococcus spp. has also been reported from various fermented food products i.e. $S$. nepalensis (Fukami et al., 2004), S. condimenti (Tanasupawat et al., 1992; Probst et al., 1998), S. xylosus, S. saprophyticus and $S$. carnosus. Although, previous researchers reported, Staphylococcus piscifermentans isolation from different fermented food products (Probst et al., 1998; Tanasupawat et al., 1992; Hazar and Hamid, 2013). Due to the long historic use in the food industry and the now verified non-pathogenic and safe status, above Staphylococcus strain are classified as a GRAS organism.

S. piscifermentans is a non-pathogenic Grampositive Staphylococcal species. It has for a long time (and is still today) been used as part of starter cultures in combination with $S$. canosus and $S$. condimentii for fish fermentation and in other food processes.

An essential function of $S$. piscifermentans in starter cultures is to prevent the growth of undesirable bacteria, thus reducing the risk of food poisoning and acting as a food preservative. Importantly, S. piscifermentans also contributes favourably to development of flavour and red color as well as to decreasing $\mathrm{pH}$ and hydrogen peroxide. Due to the many valuable and often unique properties of $S$. piscifermentans, it will most likely continue to play an important role in food processing in the future.

In the fermentation industries different genera 
of LAB such as Lactobacillus, Bifidobacterium, Pediococcus as well as many Staphylococcus strain belongs to LAB properties. In spite of vast importance, still scarcity of information on $S$. piscifermentans in food fermentation and a medical industry has been poorly known. As this strain alone, or in combination with other probiotic strains can be used as bacterial starter culture in food fermentation. Therefore, in this study, we have try to isolate and characterize, the predominant LAB strain $S$. piscifermentans from commercially important fermented fish products consumed in north-eastern regions of India, and further characterized their probiotic properties. The results obtained from this study, provide information regarding application of $S$. piscifermentans strain for developing starter culture in fish fermentation industries.

\section{Materials and Methods}

\section{Sample collection and preparation}

A total of 40 high-quality fermented fish products, commercially produced through traditional fermentation technology were purchased and analyzed during this study. Minimum ten samples of each fermented fish product viz. Shidal [Punti Shidal $(n=7)$ and Phasa Shidal $(n=3)]$ and Lonailish were collected from local markets of Tripura state (India) whereas Ngari and Hentaak collected from Manipur state (India). All samples were taken aseptically in sterile plastic bags (HiMedia, Mumbai, India) and transported to the laboratory in iced condition for further analysis.

\section{Isolation and screening of probiotic bacteria}

For the isolation of LAB, enriched and selective plating method was used. Briefly, fermented fish product (10 g) sample was mixed with $90 \mathrm{ml}$ of de Man Rogosa Sharpe (MRS) broth medium (Hi-Media, Mumbai, India) and incubated at $37{ }^{\circ} \mathrm{C}$ for overnight. Overnight grown bacterial culture was streaked on the MRS agar plate supplemented with $0.3 \% \mathrm{CaCO}_{3}$ and incubated similarly as above an-aerobically using anaerobic gas packs (HiMedia, India). Thereafter, typical colonies were selected on the basis of clear zones around the colonies indicating dissolving $\mathrm{CaCO}_{3}$ by an acid. Light yellowish colonies were picked and re-streaked on same media followed by similar incubation condition. Afterwards, purified isolates were stored in $20 \%$ glycerol at $-80^{\circ} \mathrm{C}$ for further studies.

\section{Identification of bacterial isolates}

Isolated bacterial colonies were characterized as per Bergey's Manual of Determinative Bacteriology (Holt et al., 1994). For the preliminary identification, Gram staining, catalase, oxidase, motility tests and oxidative/Fermentative (O/F) were done. Isolates showed positive result to Gram stain and catalase were assumed as Staphylococcus genus and selected for further characterization. Furthermore, these isolates were characterized for haemolytic activity, different temperatures $\left(15,30,45\right.$ and $\left.55^{\circ} \mathrm{C}\right)$ and salt concentration (2, 4, 6 and $8 \%(\mathrm{w} / \mathrm{v}))$. Furthermore, these isolates were tested for their fermentation ability to following carbohydrates: Glucose, Fructose, Mannitol, Maltose, Galactose, Sorbitol, Sucrose, Arabinose and Lactose (Himedia, Mumbai, India).

\section{Molecular characterization}

For molecular characterization, purified isolates were inoculated in nutrient broth and kept at $37^{\circ} \mathrm{C}$ for overnight incubation. Overnight grown bacterial cultures were subjected for DNA isolation using bacterial genomic DNA extraction kit (Hi-Media, 
Mumbai, India). The presence of bacterial genomic DNA was confirmed by amplification of $r p o \mathrm{~B}$ (RNA polymerase $\beta$ subunit) gene by specific primers (Febler et al., 2010). The PCR reaction was performed in thermal cycler (Thermo Electron, Germany) using cycling condition, initial denaturation at $94^{\circ} \mathrm{C}$ for 5 minute; followed by 35 cycle of denaturation at $95^{\circ} \mathrm{C}$ for $45 \mathrm{~s}$, annealing at $52^{\circ} \mathrm{C}$ for 1 minute and extension at $72^{\circ} \mathrm{C}$ for 1.5; minute and final extension at $72{ }^{\circ} \mathrm{C}$ for 10minute. The amplified products were separated by $1.2 \%$ agarose gel observed by ultraviolet transilluminator and PCR products (600bp), purified using PCR product purification kit (Himedia, India). The purified products were sequenced using forward as well as reverse primer, employing a capillary sequencer (Applied Biosystems 3500 Genetic Analyser, Thermo fisher Scientific). These partial rpoB gene sequences were analysed using NCBI-Blast software. Ten most identical sequences were selected on the basis of maximum identity scores and aligned using multiple alignment software program ClustalW. The phylogenetic tree was constructed using MEGA7 software using the Neighbour joining method. The bootstrap value was set at 1000, and percentage values are given at the nodes. The partial rpoB gene sequence submitted to NCBI GenBank database for its accession number.

\section{Determination of probiotic properties}

\section{Viability in acid and alkaline condition}

Survivability to different $\mathrm{pH}$ level (2.0, 4.0 and 8.0) was evaluated in $5 \mathrm{~mL}$ of MRS broth. Acidic $\mathrm{pH}$ was adjusted by addition of $1 \mathrm{~N} \mathrm{HCl}$ whereas for alkaline condition $1 \mathrm{~N} \mathrm{NaOH}$ was added. Fresh bacterial culture was inoculated in above broth to achieve the suspension turbidity of 0.5 McFarland standards and incubated at $37^{\circ} \mathrm{C}$ for 4 hours. Furthermore, 1 $\mathrm{mL}$ of bacterial culture from each suspension was spreaded on MRS agar plate and incubated at $37^{\circ} \mathrm{C}$ for 24 hours and survivability was checked on next day.

\section{Bile salt tolerance}

Bile salt tolerance assay was performed by adding $0.3 \%$ bile salt (SIGMA-ALDRICH®) to MRS broth. Fresh bacterial culture was inoculated in above broth to achieve the suspension turbidity of 0.5 McFarland standards and incubated at $37^{\circ} \mathrm{C}$ for 4 hours. Furthermore, $1 \mathrm{~mL}$ of bacterial culture was spreaded on MRS agar plate and incubated at $37{ }^{\circ} \mathrm{C}$ for 24 hours and survivability was checked on next day.

\section{Antibiotic sensitivity assay}

All the isolates were tested for their antibiotic sensitivity using disc diffusion method on Mueller-Hinton agar listed in Table 2. Briefly, Antibiotic discs (Himedia, India) were placed on the surface of MRS agar plates and incubated at $37^{\circ} \mathrm{C}$ for $24 \mathrm{hrs}$. Afterwards, on the basis of zone of inhibition result was interpreted as resistant (R), sensitive (S) and intermediate sensitive (IS) as per the manufacture`s protocol.

\section{Antimicrobial properties}

This test was performed in triplicates by well diffusion assay as described by Singh et al., (2010). Antagonistic spectrum of isolates was assayed using cell free neutralized supernatants (CFNS) against food borne pathogens (Bacillus subtilis, Escherichia coli, Staphylococcus aureus and Salmonella enterica).

\section{Auto-aggregation assay}

The specific cell-cell interactions were determined using auto aggregation assay. Auto aggregation assays were performed according 
to Del Re et al., (2000) with some modifications. Briefly, the overnight grown bacterial cultures were centrifuged at 5000 rpm for $10 \mathrm{~min}$ at $4^{\circ} \mathrm{C}$. Bacterial culture was washed two times in PBS and re-suspended in PBS for measuring absorbance at $600 \mathrm{~nm}$ and adjusted final concentration to $10^{9} \mathrm{CFU} / \mathrm{mL}$ using a spectrophotometer (Eppendorf, Germany). Now these bacterial suspensions were vortex for 10 seconds and incubated at $37{ }^{\circ} \mathrm{C}$ for $5 \mathrm{~h}$. The absorbance was measured at $600 \mathrm{~nm}$ using spectrophotometer. The autoaggregation was calculated with the following:

Auto-aggregation $(\%)=(1-\mathrm{At} / \mathrm{A} 0) \times 100$

Where, At represents absorbance $(600 \mathrm{~nm})$ at different time points $(\mathrm{t}=5 \mathrm{~h})$ and $\mathrm{A} 0$ represents absorbance $(600 \mathrm{~nm})$ at the beginning of the assay $(0=0 \mathrm{~h})$.

\section{Hydrophobicity assay}

Hydrophobicity assay was performed as per Crow et al., (1995) with minor modification. Briefly, overnight grown bacterial culture was centrifuged at 10,000rpm for $5 \mathrm{~min}$. The pellet was washed twice in phosphate buffer saline (PBS) and suspended in $3 \mathrm{~mL}$ of $0.1 \mathrm{M} \mathrm{KNO} 3$ solution. Afterwards, $1 \mathrm{~mL}$ of toluene was added to the above suspension in order to form a two-phase system and incubated for 10 minute at RT followed by vigorous mixing for 2 min.

Now above suspension again incubated at RT for 30 minute to separate water and toluene phases. Aqueous phase was taken carefully and measured absorbance at $600 \mathrm{~nm}$ using spectrophotometer (Eppendorf, Germany). The percentage of the cell surface hydrophobicity $(\mathrm{H})$ was calculated using the following formula:

$\mathrm{H}=(1-\mathrm{A} 1 / \mathrm{A} 0) \times 100$

Where, A1 represents absorbance $(600 \mathrm{~nm})$ of aqueous phase and $\mathrm{A} 0$ represents absorbance $(600 \mathrm{~nm})$ at the beginning of the assay.

\section{Results and Discussion}

\section{Biochemical test}

Out of sixteen, ten isolates were selected from MRS agar plate and assumed probably belonged to the Staphylococcus genus. Smooth, convex and yellowish coloured colonies on MRS agar plates were identified as Staphylococcus spp. on the basis of biochemical tests (Table 1). The bacteria were Gram-positive coccus shaped, catalase positive, coagulase negative and fermentative. All selected isolates of $S$. piscifermentans grow well at different temperature ranges (15, 30,45 and $\left.55^{\circ} \mathrm{C}\right)$ as well as various salt concentrations $(2 \%, 4 \%, 6 \%$ and $8 \%)$.

One another most important characteristic of these isolates, they were given no haemolysis $(\gamma$-hemolysis) activity on sheep blood agar plate (Fig. 1b). Furthermore, all selected isolates showed fermentative reaction to various sugars viz. glucose, fructose, galactose, maltose, sorbitol and lactose whereas unable to ferment arabinose, sucrose and mannitol (Table 1).

\section{Molecular characterisation}

PCR reaction of all selected isolates of rpoB gene gives amplification product of $600 \mathrm{bp}$ (Fig. 2). Multiple sequence alignment of rpoB gene sequences of the selected isolates from fermented fish products indicated that all these sequences were identical and therefore, only one sequences was submitted to GenBank with Accession Number: KX582169.1. The phylogenetic tree shows maximum similarity (100\%) of our isolate with S. piscifermentans strain CCM 7165 (GenBank Accession Number: HM146320.1) by forcing $L$. plantarum strain DSM 20174 (GenBank 
Accession Number: AF515652.1) as outgroup with 1000 bootstrap value (Fig. 3).

\section{Probiotic properties of tested isolates:}

\section{Viability in acid and alkaline condition}

All the selected isolates of $S$. piscifermentans showing survivability at different range of $\mathrm{pH}$ values acidic as well as alkaline (2.0, 4.0 and 8.0), results are listed in Table 1.

\section{Growth on bile salt}

The results of bile salt tolerance revealed that all the isolates of S. piscifermentans viable on MRS agar plates and survival rates observed $69.6 \%$ to $86.0 \%$ which showed that all tested strains were resistant to bile salt $(0.3 \%)$.

\section{Antibiotic test}

Results of antibiotic sensitivity test were given in Table 2. The results of sensitivity recorded on based on zone of inhibition after 24 hour of incubation and it observed that all the ten isolates were sensitive to most of the antibiotics.

\section{Antimicrobial test}

All tested isolates were revealed antimicrobial activity against Staphylococcus aureus and E. coli pathogenic strain, whereas, no effect was found against Salmonella enterica and Bacillus subtilus. Maximum zone of inhibition $(6 \mathrm{~mm})$ was found against pathogenic strain of E. coli (Fig. 1a).

\section{Auto aggregation and hydrophobicity assay}

All tested isolates exhibited moderate hydrophobicity indicated as the value observed above $33.4 \%$ whereas, autoaggregation ability found $73.29 \%$.

In this Era, Fermented foods are in high demands in most of the countries as these foods constitute a major part of human diet due to many virtues properties. The virtues properties of fermented foods are because of many residing bacteria or LAB. These LAB have the properties to preserves food, improve nutritional value and boosts sensory properties (Ahmed et al., 2013). Diverse group of LAB such as Lactobacillus (Matsui et al., 2010), Pediococcus (Doyle et al., 2001), Staphylococcus (Zaman et al., 2011) and Bacillus (Toyokawa et al., 2010) has reported in various fermented fish products.

Beyond this, demand is currently increasing for new LAB strain candidates (Argyri et al., 2013) which could be used as starter culture. Though, numbers of studies have been performed to revealing the microbial diversity of the various fermented fish products of Northeast India (Tamnga, 2003; Sohliya et al., 2009), but scarcity of the literature regarding $S$. piscifermentans from fermented fish product viz. Shidal, lonailsh, Ngari and Hentak is seems.

It is well known that $S$. piscifermentans, reported from fermented foods such as sausages (Tanasupawat et al., 1992), fish (Tanasupawat et al., 1992; Hazar and Hamid, 2013), and other food (Probst et al., 1998), however, in our knowledge this is the first report of $S$. piscifermentans in selected fermented fish products.

In the present study, viewing in aim we have isolated the predominant LAB strain $S$. piscifermentans from the four commercially important fermented fish products of India. This strain was identified and characterized by biochemical as well as molecular methods, besides this various probiotic properties; such as resistant to acid and alkali, bile salt tolerance, antimicrobial and antibiotic activities was also evaluated. 
Fig.1 (a) Zone of inhibition of Staphylococcus piscifermentans against E. coli. (b) Shows $\gamma$ haemolysis by the potent isolate against a suitable reference strain.
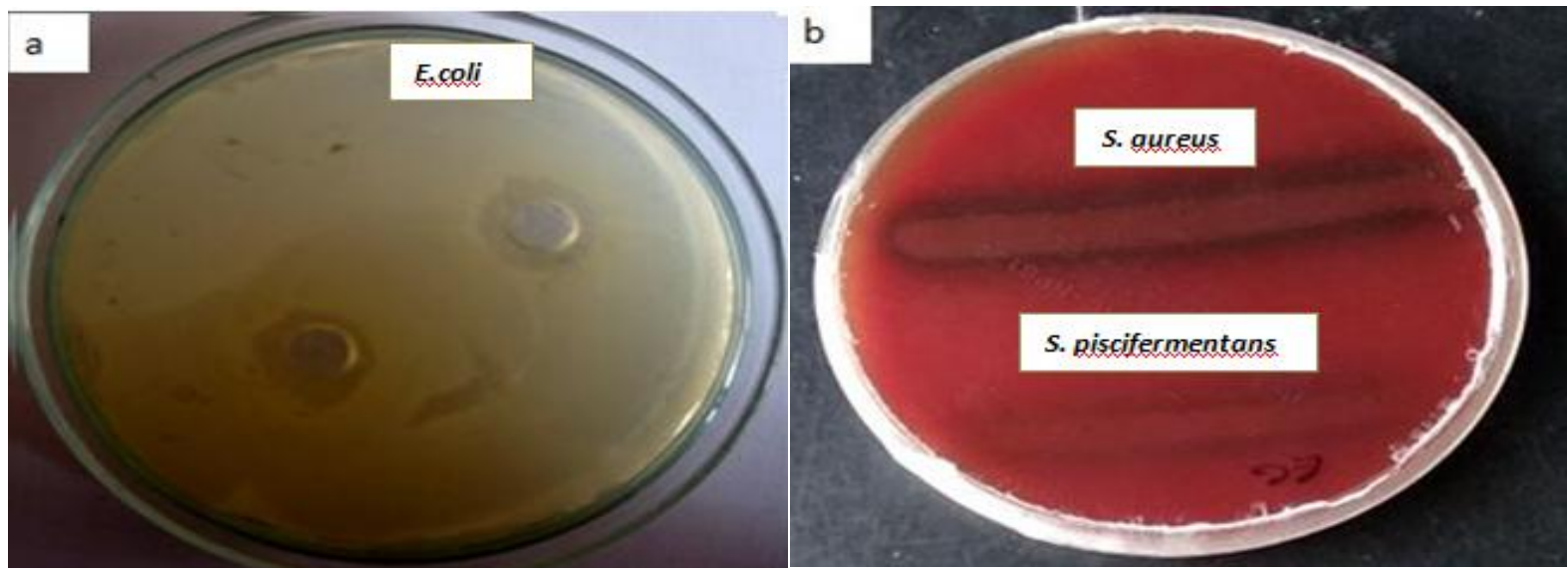

Fig.2 Amplification of rpoB region of S. piscifermentans Lane L: 100bp DNA ladder (Thermoscientific), Lane 1-10: Isolates of $S$. piscifermentans

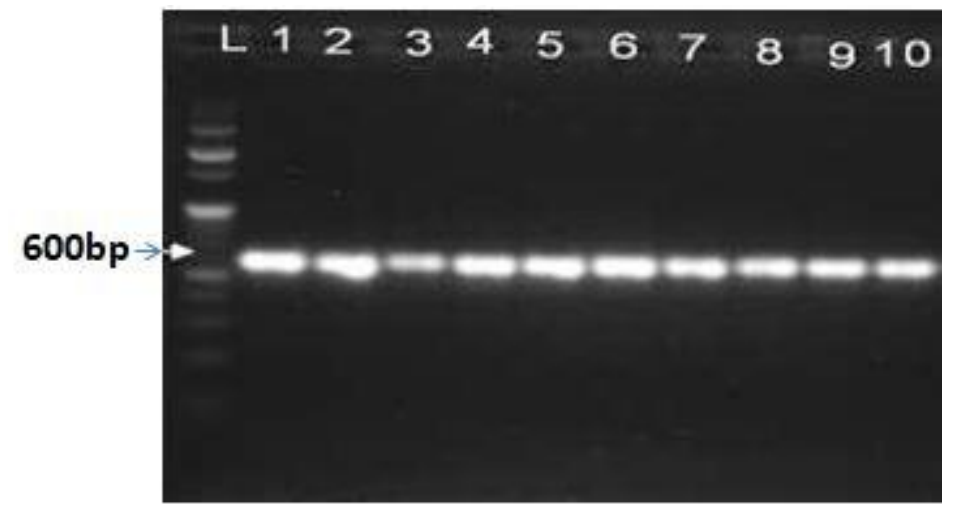

Fig.3 Phylogenetic relationship of Staphylococcus piscifermentans from fermented fish products with selected members of other species within the genus Staphylococcus on basis of partial sequence of rpoB gene

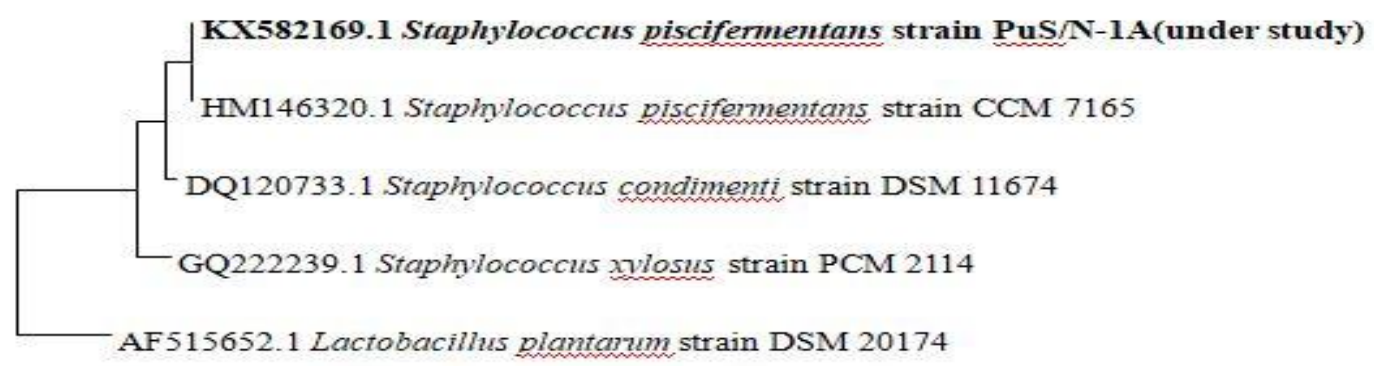


Table.1 Biochemical characteristics of the LAB strain S. piscifermentans isolates from different fermented fish samples

\begin{tabular}{|c|c|c|c|c|c|c|c|c|c|c|}
\hline \multirow[t]{2}{*}{ Characteristics } & \multicolumn{10}{|c|}{ Isolate Strain of Staphylococcus piscifermentans } \\
\hline & $\begin{array}{l}\mathrm{PuS} \\
* / \mathrm{N}- \\
1 \mathrm{~A}\end{array}$ & $\begin{array}{l}\mathrm{PuS} \\
* / \mathrm{N}- \\
6\end{array}$ & $\begin{array}{l}\mathrm{PuS} * / \\
\mathrm{N}-7\end{array}$ & $\begin{array}{l}\mathrm{N} * / \\
\mathrm{N}-1\end{array}$ & $\begin{array}{l}\mathrm{N} * / \\
\mathrm{N}-7\end{array}$ & $\begin{array}{l}\mathrm{N} * / \\
\mathrm{N}-8\end{array}$ & $\begin{array}{l}\mathrm{N} * / \\
\mathrm{N}- \\
10\end{array}$ & $\begin{array}{l}\mathrm{L} * / \\
\mathrm{N}- \\
3 \mathrm{~A}\end{array}$ & $\begin{array}{l}\mathrm{L}^{*} / \\
\mathrm{N}- \\
3 \mathrm{~B}\end{array}$ & $\begin{array}{l}\mathrm{H}^{*} / \\
\mathrm{N}-6\end{array}$ \\
\hline Gram stain & + & + & + & + & + & + & + & + & + & + \\
\hline Shape & $\begin{array}{l}\text { Coc } \\
\text { cus }\end{array}$ & $\begin{array}{l}\text { Coc } \\
\text { cus }\end{array}$ & $\begin{array}{l}\text { Coccu } \\
\text { S }\end{array}$ & $\begin{array}{l}\text { Coc } \\
\text { cus }\end{array}$ & $\begin{array}{l}\text { Coc } \\
\text { cus }\end{array}$ & $\begin{array}{l}\text { Coc } \\
\text { cus }\end{array}$ & $\begin{array}{l}\text { Coc } \\
\text { cus }\end{array}$ & $\begin{array}{l}\text { Coc } \\
\text { cus }\end{array}$ & $\begin{array}{l}\text { Coc } \\
\text { cus }\end{array}$ & $\begin{array}{l}\text { Coc } \\
\text { cus }\end{array}$ \\
\hline Catalase & + & + & + & + & + & + & + & + & + & + \\
\hline Oxidase & - & - & - & - & - & - & - & - & - & - \\
\hline Motility & - & - & - & - & - & - & - & - & - & - \\
\hline Cagolase & - & - & - & - & - & - & - & - & - & - \\
\hline $\mathrm{O} / \mathrm{F}$ test & $\mathrm{F}$ & $\mathrm{F}$ & $\mathrm{F}$ & $\mathrm{F}$ & $\mathrm{F}$ & $\mathrm{F}$ & $\mathrm{F}$ & $\mathrm{F}$ & $\mathrm{F}$ & $\mathrm{F}$ \\
\hline \multicolumn{11}{|c|}{ Carbohydrate utilisation test } \\
\hline Glucose & + & + & + & + & + & + & + & + & + & + \\
\hline Fructose & + & + & + & + & + & + & + & + & + & + \\
\hline Galactose & + & + & + & + & + & + & + & + & + & + \\
\hline Maltose & + & + & + & + & + & + & + & + & + & + \\
\hline Sorbitol & + & + & + & + & + & + & + & + & + & + \\
\hline Lactose & + & + & + & + & + & + & + & + & + & + \\
\hline Arabinose & - & - & - & - & - & - & - & - & - & - \\
\hline Sucrose & - & - & - & - & - & - & - & - & - & - \\
\hline Mannitol & - & - & - & - & - & - & - & - & - & - \\
\hline
\end{tabular}

\section{Growth at different temperature}

\begin{tabular}{|c|c|c|c|c|c|c|c|c|c|c|}
\hline $15^{\circ} \mathrm{C}$ & + & + & + & + & + & + & + & + & + & + \\
\hline $30^{\circ} \mathrm{C}$ & + & + & + & + & + & + & + & + & + & + \\
\hline $45^{\circ} \mathrm{C}$ & + & + & + & + & + & + & + & + & + & + \\
\hline $5^{\circ} \mathrm{C}$ & + & + & + & + & + & + & + & + & + & + \\
\hline
\end{tabular}

\section{Growth at different salt concentrarion}

\begin{tabular}{|l|l|l|l|l|l|l|l|l|l|l|}
$2 \%$ & + & + & + & + & + & + & + & + & + & + \\
\hline $4 \%$ & + & + & + & + & + & + & + & + & + & + \\
\hline $6 \%$ & + & + & + & + & + & + & + & + & + & + \\
\hline $8 \%$ & + & + & + & + & + & + & + & + & + & + \\
\hline
\end{tabular}

\begin{tabular}{ll|l|l|l|l|l|l|l|l|l|l|}
\hline pH 2 & + & + & + & + & + & + & + & + & + & + \\
\hline pH 4 & + & + & + & + & + & + & + & + & + & + \\
\hline pH 6 & + & + & + & + & + & + & + & + & + & + \\
\hline pH 8 & + & + & + & + & + & + & + & + & + & + \\
\hline $\begin{array}{l}\text { Growth on } \\
\text { 0.3\% bile salt }\end{array}$ & + & + & & + & + & + & + & + & + & + & + \\
\hline
\end{tabular}

PuS*- Punti Shidal, N*- Ngari, L*- Lonailish, $\mathrm{H}^{*}$ - Hentaak 
Table.2 Antibiotic sensitivity test of all presumptive S. piscifermentans strain

\begin{tabular}{|c|c|c|c|c|c|c|c|}
\hline \multirow{2}{*}{$\begin{array}{l}\text { S. piscifermentans } \\
\text { Isolates }\end{array}$} & \multicolumn{7}{|c|}{ Antibiotics } \\
\hline & $\begin{array}{l}E^{*} \\
(15 \mathrm{mcg})\end{array}$ & $\begin{array}{l}\mathrm{NX}^{*} \\
(10 \mathrm{mcg})\end{array}$ & $\begin{array}{l}\text { COT* }^{*} \\
(25 \mathrm{mcg})\end{array}$ & $\begin{array}{l}\text { AMP* } \\
(10 \text { mcg) }\end{array}$ & $\begin{array}{l}\text { CIP* } \\
\text { (30 mcg) }\end{array}$ & $\begin{array}{l}S^{*} \\
(30 \mathrm{mcg})\end{array}$ & $\begin{array}{l}\mathrm{VN}^{*} \\
(25 \mathrm{mcg})\end{array}$ \\
\hline PuS*/N-1A & $\mathrm{S}$ & $\mathrm{S}$ & $\mathrm{R}$ & $\mathrm{S}$ & $\mathrm{S}$ & $\mathrm{S}$ & $\mathrm{S}$ \\
\hline PuS*/N-6 & $S$ & S & $\mathrm{R}$ & S & S & $S$ & $S$ \\
\hline PuS*/N-7 & S & S & $\mathrm{R}$ & S & S & S & S \\
\hline $\mathrm{N} * / \mathrm{N}-1$ & S & S & $\mathrm{R}$ & S & S & S & S \\
\hline $\mathbf{N} * / \mathbf{N}-7$ & S & S & $\mathrm{R}$ & S & S & S & S \\
\hline $\mathrm{N} * / \mathrm{N}-8$ & S & S & $\mathrm{R}$ & $\mathrm{S}$ & S & S & S \\
\hline $\mathrm{N} * / \mathrm{N}-10$ & $\mathrm{~S}$ & S & $\mathrm{R}$ & $\mathrm{S}$ & S & $S$ & $\mathrm{~S}$ \\
\hline L*/N-3A & S & S & $\mathrm{R}$ & S & S & S & S \\
\hline L*/N-3B & $\mathrm{S}$ & $S$ & $\mathrm{R}$ & $\mathrm{S}$ & $S$ & $S$ & $\mathrm{~S}$ \\
\hline $\mathrm{H} * / \mathrm{N}-6$ & $\mathrm{~S}$ & $S$ & $\mathrm{R}$ & $\mathrm{S}$ & S & $S$ & $\mathrm{~S}$ \\
\hline
\end{tabular}

PuS*- Punti Shidal, N*- Ngari, L*- Lonailish, H*- Hentaak

(S)- Sensitive, (R) - Resistant, (ID) - Intermediate

*Antibiotic discs:; E- Erythromycin; NX- Norfloxacin; COT- Co-Trimoxazole; CIP- Ciprofloxacin; SStreptomycin; VN- Vancomycin

Out of 16,10 isolates were selected from different fermented fish products $(\mathrm{n}=40)$ due to clear zones around the colony on the MRS agar $\left(0.3 \% \mathrm{CaCO}_{3}\right)$ (Panthavee et al., 2007). Further on biochemical characterization, these lactic acid bacteria were give positive results for Gram staining as well as catalase and oxidase tests whereas negative for coagulase. On the basis of above results these isolates suspected as Staphylococcus genus. Our results are in conformity with previous reports (Schleifer and Fischer, 1982). Furthermore, all selected isolates showed fermentative reaction to various sugars viz. glucose, fructose, galactose, maltose, sorbitol and lactose whereas, unable to ferment arabinose, sucrose and mannitol.

On sequencing of rpoB gene of the selected isolates (acc. KX582169.1), it exhibited 100\% similarity with $S$. piscifermentans (acc. HM146320.1) (Švec et al., 2010). Our results are in conformity with previous reports (Švec et al., 2010). In the present study, rpoB gene is used, because of very high interspecies sequence similarity (90 to 99\%) displayed by Staphylococcal species instead of 16S rRNA gene which give questionable results at the species level (Ghebremedhin et al., 2008).

Furthermore, these isolates were further tested to evaluate their probiotic properties. As it is concerned that gastric juice in stomach has $\mathrm{pH}$ range between 1.5 and 3.0, which acts as a biological barrier. Our isolates are grown well at low range of $\mathrm{pH}$ values (2.0 and 4.0) as well as high $\mathrm{pH}$ value (8.0) till $5 \mathrm{hr}$ of incubation, which are similar to previous reports of Tanasupawat et al., (1992) and Borah et al., (2016). That is showing its capacity to pass through the acidic environment of stomach as well as the alkaline conditions of GI tract (Corzo and Gilliland, 1999).

In addition, selected Staphylococcus isolates were evaluated to viability at $0.3 \%$ bile salt concentration. The relevant physiological bile salt concentration in human GI tract is reported around $0.3-0.5 \%$ (Vlkovál et al., 2012), and resistance to this concentration is considered good enough to select probiotic strains (Goldin and Gorbach, 1992). Our results are in conformity to previous reports 
of isolation of $S$. piscifermentans isolated from fermented meat product (Borah et al., 2016) and to other LAB strains from different environments (Vinderola et al., 2008; Zago et al., 2011; Ramos et al., 2013).

The antagonistic activity displayed by the majority of LAB strain may be due to the production of organic acids, hydrogen peroxide $\left(\mathrm{H}_{2} \mathrm{O}_{2}\right)$, diacetyl (2,3-butanedione) and bacteriocins (Hassan et al.,; 2012). Among them, bacteriocins have enormous potential to inhibit many harmful microbes responsible for spoilage of food and for future it could be seen as next generation antimicrobial agent, which might be helpful to target the multi-drug resistant pathogens (Perez et al., 2014). Now a day, much attention is towards the bio-preservation rather than chemical preservation in food processing industries. As shown in Figure 1a, the antimicrobial properties of tested isolates against E. coli, Staphylococcus aureus, Bacillus subtilis and Salmonella enterica revealed that these tested isolates displayed wide inhibitory action against most severe bacterial pathogens, E. coli and $S$. aureus. Elyass et al., (2015) reported similar antimicrobial activity of $S$. piscifermentas isolated from fermented Sundease beef. In addition, inhibition of $S$. aureus by $S$. piscifermentas was also reported by Heikkila and Saris (2003) and Hajar and Hamid (2013).

Antibiotic sensitivity test seems to be other important criteria with regard to medical concern and probiotic strain as wide array of antibiotics resistant strains are present among pathogenic bacteria (Lee et al., 2014). In addition to, all Staphylococcus spp. shows wide range of resistance against antibiotics (Myllys, 1995), whereas, during this study we found that $S$. piscifermentans displayed a substantially lesser resistance to antibiotics, indicating non-pathogenic property of this strain. This result is supported by Resch et al., (2008) and Borah et al., (2016).

Aggregation is an important property to criterion of probiotic (Kaushik et al., 2009) Auto-aggregation with co-aggregation plays important role in adhesion to intestinal epithelial cells as well as help to form barrier to prevents pathogen colonization (Del Re et $a l ., 2000)$. The results of this study displayed higher values of auto-aggregation in the range of 25.1 to $62.5 \%$ ). Our results are in conformity with earlier reports of $L$. acidophilus (Kos et al., 2003); Bifidobacterium longum (Del Re et al., 2000) and lactic acid bacteria (Collado et al., 2007).

Hydrophobicity is physico-chemical properties which help to microorganism to hod or connect to the host cells (Shobharani and Agrawal, 2011). Hence, hydrophobicity indicates the capability of probiotic strain to attachment with the epithelial cell lining of the intestine and resists the movement of digested food materials (Chauvière et al., 1992). It is well known that probiotic microbes showed higher hydrophobicity as compared to pathogens, suggesting the specific binding capacity of probiotics in the gastro intestinal tract. All the selected strain displayed good hydrophobicity, similar results was reported by Borah et al., (2016).

The Northeast region of India is bestowed with many fermented fish products such as Shidal, Ngari, Hentaak, Lonailish, Tungtap and many more. Four varieties of fermented fish products such as Shidal (both Punti and Phasa Shidal) and Lonailish of Tripura and Ngari and Hentaak of Manipur has been studied to investigate the predominant bacteria supposed to be involved in fermentation. It is well known that, the indigenous microbiota of these fermented products is loaded with potential autochthonous starter cultures; which could 
promote the growth of undesirable microbiota due to hygienic or technological omissions. Since, identification of predominant bacteria is the prime requirement to develop starter culture for improvement of the very old age technology of fish fermentation, to achieve this goal; we have tried to isolates and identify the predominant bacteria and their probable role in fermentation and also evaluate their probiotic property. In the present study, the predominant LAB strain $S$. piscifermentans was isolated from four commercial fermented fish products and characterized by biochemical and molecular methods. Furthermore, isolates were tested for resistance to acid as well as bile tolerance, antimicrobial and antibiotic sensitivity test, the key features to consider bacterial strains as probiotic.

\section{Acknowledgement}

The authors are thankful to Dean, College of fisheries, Central Agriculture University, Tripura for providing guidance and necessary facilities.

\section{References}

Ahmed, Z., Wang, Y., Ahmad, A., Khan, S.T., Nisa, M., Ahmad, H. and Afreen, A., 2013. Kefir and health: a contemporary perspective. Critical reviews in food science and nutrition, 53(5), pp.422-434.

Argyri, A.A., Zoumpopoulou, G., Karatzas, K.A.G., Tsakalidou, E., Nychas, G.J.E., Panagou, E.Z. and Tassou, C.C., 2013. Selection of potential probiotic lactic acid bacteria from fermented olives by in vitro tests. Food microbiology, 33(2), pp.282-291.

Blandino, A., Al-Aseeri, M.E., Pandiella, S.S., Cantero, D. and Webb, C., 2003. Cereal-based fermented foods and beverages. Food research international, 36(6), pp.527-543.

Borah, D., Gogoi, O., Adhikari, C. and Kakoti, B.B., 2016. Isolation and characterization of the new indigenous Staphylococcus sp. DBOCP06 as a probiotic bacterium from traditionally fermented fish and meat products of Assam state. Egyptian Journal of Basic and Applied Sciences, 3(3), pp.232-240.

Chauvière, G., Coconnier, M.H., Kerneis, S., Darfeuille-Michaud, A., Joly, B. and Servin, A.L., 1992. Competitive exclusion of diarrheagenic Escherichia coli (ETEC) from human enterocytelike Caco-2 cells by heat-killed Lactobacillus. FEMS Microbiology Letters, 91(3), pp. 213-217.

Collado, M.C., Surono, I., Meriluoto, J. and Salminen, S., 2007. Indigenous Dadih Lactic Acid Bacteria: Cell- Surface Properties and Interactions with Pathogens. Journal of food science, 72(3).

Corzo, G. and Gilliland, S.E., 1999. Bile Salt Hydrolase Activity of Three Strains of Lactobacillus acidophilus1.Journal of Dairy Science, 82(3), pp.472-480.

Crow, V.L., Gopal, P.K. and Wicken, A.J., 1995. Cell surface differences of lactococcal strains. International Dairy Journal, 5(1), pp. 45-68.

Del Re, B., Sgorbati, B., Miglioli, M. and Palenzona, D., 2000. Adhesion, autoaggregation and hydrophobicity of 13 strains of Bifidobacterium longum. Letters in applied microbiology, 31(6), pp.438-442.

Di Cagno, R., Coda, R., De Angelis, M. and Gobbetti, M., 2013. Exploitation of vegetables and fruits through lactic acid fermentation. Food Microbiology, 33(1), pp.1-10.

Doyle, P. M., Beuchat, R. L. and Montville, J. T., 2001. Food microbiology, 2nd ed. 
ASM Press, Washington, DC, U.S.A, pp. 681-695.

Elmadfa, I., Klein, P. and Meyer, A.L., 2010. Immune-stimulating effects of lactic acid bacteria in vivo and in vitro. Proceedings of the Nutrition Society, 69(3), pp.416-420.

Elyass, M.E., Altayar, M.A., Mahdi, A.A., Abdelrawaf, S.A., Shigidi, M.T. and Attitalla, I.H., 2015. Characterization and Evaluation of Antimicrobial Activity of Bacteriocins from Lactobacillus curvatus and Pediococcus pentosaceus. Journal of Microbial Pathophysiology \& Pathogenesis, 1, pp.1-7.

Febler, A.T., Billerbeck, C., Kadlec, K. and Schwarz, S., 2010. Identification and characterization of methicillin-resistant coagulase-negative staphylococci from bovine mastitis. Journal of antimicrobial chemotherapy, 65(8), pp.1576-1582.

Fontana, L., Bermudez-Brito, M., Plaza-Diaz, J., Munoz-Quezada, S. and Gil, A., 2013. Sources, isolation, characterisation and evaluation of probiotics. British journal of nutrition, 109(S2), pp. S35-S50.

Fukami, K., Satomi, M., Funatsu, Y., KAWASAKI, K.I. and Watabe, S., 2004. Characterization and distribution of Staphylococcus sp. implicated for improvement of fish sauce odour. Fisheries science, 70(5), pp.916-923.

Ghebremedhin, B., Layer, F., König, W. and König, B., 2008. Genetic classification and distinguishing of Staphylococcus species based on different partial gap, 16S rRNA, hsp60, rpoB, sodA, and tuf gene sequences. Journal of clinical microbiology, 46(3), pp.1019-1025.

Goldin, B.R., Gorbach, S.L., Saxelin, M., Barakat, S., Gualtieri, L. and Salminen, S., 1992. Survival of Lactobacillus species (strain GG) in human gastrointestinal tract. Digestive diseases and sciences, 37(1), pp.121-128.

Gong, J., Bai, T., Zhang, L., Qian, W., Song, J. and Hou, X., 2017. Inhibition effect of Bifidobacterium longum, Lactobacillus acidophilus, Streptococcus thermophilus and Enterococcus faecalis and their related products on human colonic smooth muscle in vitro. PloS one, 12(12), p.e0189257.

Hajar, S. and Hamid, T. H. T. A., 2013. Isolation of lactic acid bacteria strain Staphylococcus piscifermentans from Malaysian traditional fermented shrimp cincaluk. International Food Research Journal, 20(1): 125-129.

Hassan, M., Kjos, M., Nes, I.F., Diep, D.B. and Lotfipour, F., 2012. Natural antimicrobial peptides from bacteria: characteristics and potential applications to fight against antibiotic resistance. Journal of applied microbiology, 113(4), pp.723-736.

Heikkilä, M.P. and Saris, P.E.J., 2003. Inhibition of Staphylococcus aureus by the commensal bacteria of human milk. Journal of applied microbiology, 95(3), pp.471-478.

Holt, J.G., Krieg, N.R., Sneath, P.A., Staley, J.T. and Williams, S.T., 1994. Bergey's Manual of determinate bacteriology.

Jeyaram, K., Singh, T. H., Romi, W., Devi, A. R., Singh, W. M., Dayanidhi, H., Singh, N. R. and Tamang, J. P., 2009. Traditional fermented foods of Manipur. Indian Journal of Traditional Knowledge, 8(1): 115-121.

Kaushik, J.K., Kumar, A., Duary, R.K., Mohanty, A.K., Grover, S. and Batish, V.K., 2009. Functional and probiotic attributes of an indigenous isolate of Lactobacillus plantarum. PloS one, 4(12), p. e8099. 
Khan U.S., 2014. Probiotics in dairy foods: a review. Nutrition \& Food Science, 44(1), pp.71-88.

Kos, B.V.Z.E., Šušković, J., Vuković, S., Šimpraga, M., Frece, J. and Matošić, S., 2003. Adhesion and aggregation ability of probiotic strain Lactobacillus acidophilus M92. Journal of applied microbiology, 94(6), pp.981-987.

Lee, K.W., Park, J.Y., Sa, H.D., Jeong, J.H., Jin, D.E., Heo, H.J. and Kim, J.H., 2014. Probiotic properties of Pediococcus strains isolated from jeotgals, salted and fermented Korean sea-food. Anaerobe, 28, pp.199-206.

Matsui, H., Saka, E., Isobe, Y. and Narita, M., 2010. Comparison of the bacterial community structures of Ayu-narezushi produced by two different manufacturers. Biocontrol science, 15(2), pp.63-68.

Montet, D., Panda, S.K., Ray, R.C. and Mishra, S.S., 2017. Technological Innovations in Processing of Fermented Foods an Overview. In Fermented Foods, Part II (pp. 21-45). CRC Press.

Muro Urista, C., Álvarez Fernández, R., Riera Rodriguez, F., Arana Cuenca, A. and Tellez Jurado, A., 2011. Production and functionality of active peptides from milk. Food Science and Technology International, 17(4), pp.293-317.

Myllys, V., 1995. Staphylococci in heifer mastitis before and after parturition. Journal of Dairy Research, 62(1), pp.51-60.

Narzary, Y., Brahma, J., Brahma, C. and Das, S., 2016. A study on indigenous fermented foods and beverages of Kokrajhar, Assam, India. Journal of Ethnic Foods, 3(4), pp.284-291.

Ouwehand, A.C. and Vesterlund, S., 2004. Antimicrobial components from lactic acid bacteria. FOOD SCIENCE AND TECHNOLOGY-NEW YORK-MARCEL DEKKER-, 139, pp.375-396.
Panthavee, W., Pramuan, S. and Nasakom, W., 2007. Identification and evaluation of lactic acid bacteria for Pla-som (fermented fish) starter. In The 2nd International Conference on Fermentation Technology for Value Added Agricultural Products (pp. 2325).

Papadimitriou, K., Pot, B. and Tsakalidou, E., 2015. How microbes adapt to a diversity of food niches. Current Opinion in Food Science, 2, pp.29-35.

Perez, R.H., Zendo, T. and Sonomoto, K., 2014, August. Novel bacteriocins from lactic acid bacteria (LAB): various structures and applications. In Microbial cell factories (Vol. 13, No. 1, p. S3). BioMed Central.

Probst, A.J., Hertel, C., Richter, L., Wassill, L., Ludwig, W. and Hammes, W.P., 1998. Staphylococcus condimenti sp. nov., from soy sauce mash, and Staphylococcus carnosus (Schleifer and Fischer 1982) subsp. utilis subsp. nov. International Journal of Systematic and Evolutionary Microbiology, 48(3), pp.651-658.

Ramos, C.L., Thorsen, L., Schwan, R.F. and Jespersen, L., 2013. Strain-specific probiotics properties of Lactobacillus fermentum, Lactobacillus plantarum and Lactobacillus brevis isolates from Brazilian food products. Food microbiology, 36(1), pp.22-29.

Resch, M., Nagel, V. and Hertel, C., 2008. Antibiotic resistance of coagulasenegative staphylococci associated with food and used in starter cultures. International journal of food microbiology, 127(1-2), pp.99-104.

Schleifer, K.H. and Fischer, U., 1982. Description of a new species of the genus Staphylococcus: Staphylococcus carnosus. International Journal of Systematic and Evolutionary Microbiology, 32(2), pp.153-156. 
Shobharani, P. and Agrawal, R., 2011. A potent probiotic strain from cheddar cheese. Indian journal of microbiology, 51(3), pp.251-258.

Sohliya, I., Joshi, S.R., Bhagobaty, R.K. and Kumar, R., 2009. Tungrymbai-A traditional fermented soybean food of the ethnic tribes of Meghalaya.

Švec, P., Pantůček, R., Petráš, P., Sedláček, I. and Nováková, D., 2010. Identification of Staphylococcus spp. using (GTG) 5PCR fingerprinting. Systematic and applied microbiology, 33(8), pp.451456.

Tamang, J.P. 2003. Native microorganisms in the fermentation of Kinema. Int. J. Food Microbiol. 43, 127-130.

Tamang, J.P., Tamang, N., Thapa, S., Dewan, S., Tamang, B., Yonzan, H., Rai, A.K., Chettri, R., Chakrabarty, J. and Kharel, N., 2012. Microorganisms and nutritional value of ethnic fermented foods and alcoholic beverages of North East India.

Tanasupawat, S., Hashimoto, Y., Ezaki, T., Kozaki, M. and Komagata, K., 1992. Staphylococcus piscifermentans $\mathrm{sp}$. nov., from fermented fish in Thailand. International Journal of Systematic and Evolutionary Microbiology, 42(4), pp.577-581.

Toyokawa, Y., Takahara, H., Reungsang, A., Fukuta, M., Hachimine, Y., Tachibana, S. and Yasuda, M., 2010. Purification and characterization of a halotolerant serine proteinase from thermotolerant Bacillus licheniformis RKK-04 isolated from Thai fish sauce. Applied microbiology and biotechnology, 86(6), pp.1867-1875.

Vinderola, G., Capellini, B., Villarreal, F., Suárez, V., Quiberoni, A. and Reinheimer, J., 2008. Usefulness of a set of simple in vitro tests for the screening and identification of probiotic candidate strains for dairy use. $L W T$ Food Science and Technology, 41(9), pp.1678-1688.

Visessanguan, W., Benjakul, S., Smitinont, T., Kittikun, C., Thepkasikul, P. and Panya, A., 2006. Changes in microbiological, biochemical and physico-chemical properties of Nham inoculated with different inoculum levels of Lactobacillus curvatus. LWTFood Science and Technology, 39(7), pp.814-826.

Vlková, E., Kalous, L., Bunešová, V., Rylková, K., Světlíková, R. and Rada, V., 2012. Occurrence of Bifidobacteria and Lactobacilli in digestive tract of some freshwater fishes. Biologia, 67(2), pp.411-416.

Zago, M., Fornasari, M.E., Carminati, D., Burns, P., Suàrez, V., Vinderola, G., Reinheimer, J. and Giraffa, G., 2011. Characterization and probiotic potential of Lactobacillus plantarum strains isolated from cheeses. Food Microbiology, 28(5), pp.1033-1040.

Zaman, M.Z., Bakar, F.A., Jinap, S. and Bakar, J., 2011. Novel starter cultures to inhibit biogenic amines accumulation during fish sauce fermentation. International journal of food microbiology, 145(1), pp.84-91.

\section{How to cite this article:}

Shubham Gupta, Ravindra, Pradip K. Maurya, Janmejay Parhi, Sanjeev Sharma, Sanjay Chandravanshi and Ranendra K. Majumdar. 2018. Isolation and Characterization of Predominant Bacteria, Staphylococcus piscifermentans Associated with Traditional Fermented Fish Products of Northeast India. Int.J.Curr.Microbiol.App.Sci. 7(05): 1758-1771. doi: https://doi.org/10.20546/ijcmas.2018.705.205 